\title{
TECHNICAL AND ECONOMIC ASPECTS OF REVITALIZATION OF DOWN-TOWN TENEMENT-HOUSES IN WROCLAW
}

\author{
Ewa MARCINKOWSKA, Krzysztof GAWRON, Mariusz REJMENT \\ Department of Construction Methods and Management, Faculty of Civil Engineering, \\ Wrocław University of Technology, 11 Grunwaldzki Sq., 50-377 Wroctaw, Poland
}

Received 07 Oct 2014; accepted 17 Nov 2014

\begin{abstract}
In the paper the authors examined the relations between the physical deterioration degree and the price of the tenement-houses in Wrocław. The researches concern the year's 1991-2009. According to the following analyses: technical, technical-economic (concerning the relations between buildings technical condition and buildings price) and economic the authors have come the conclusions concerning the sensibility of the revitalization work. The authors also estimated the purchase limit profitability of the tenement-houses, which are going to be repaired and modernized or to be demolished and next to be built a new tenement-house. The direction of the engineering activities was shown. They could improve the economic effectiveness of the revitalized tenement-houses.
\end{abstract}

Keywords: revitalization of apartment buildings, building development of Wrocław in the beginning of the XX century, physical deterioration degree of buildings, economic effectiveness of revitalization.

\section{Introduction}

Since the moment of Poland accession to the European Community it has been observed the increased interest of foreign investors in projects in the borderlands (e.g. in the Lower Silesia region) and particularly in the city of Wrocław.

The main subjects of interest of foreign investors are the lands (building lots) on the outskirts of the town (where industrial buildings and widely-known servicing are situated) and the down-town (where investors seek places for prestige apartment buildings, hotels, restaurants, head offices for firms).

The down-town area of Wrocław surrounds the oldest, centrally situated part of the town and the building development of its space followed together with the industrial revolution on the turn of the XIX century and it lasted till the I World War. Nowadays the arrangement of streets in the down-town area of Wrocław remains the same as it was designed and built originally. The streets arrangement creates the scenery/image, which decides about the down-town character and appearance. The streets are built from both sides by the apartment buildings with the neoclassical style. The façades of the apartment buildings are often decorated with the Art Nouveau elements. The apartment buildings, erected in that period of time, are characterised by the considerable number of the separate apartments. The apartments' standards change together with a building story and sometimes with the use of a first floor space for commercial purpose. The above apartment buildings have the similar material and construction solutions. They create a group of buildings, which is named in the Polish language by a term "tenement-houses".

The tenement-houses situated in the down-town part of Wrocław, built before the I World War, generally have four or five stories. Each story has a different height. They are built of bricks; they most often have three sections, with longitudinal load-bearing walls, with solid floors over cellars (usually brick segmental barrel vault) and wooden floors over the next stories. The longitudinal load-bearing walls of the internal section are usually characterized by the low load capacity of their foundations, what makes very difficult to replace wooden floors on the solid ones (and at the same time increases the repair/ modernization costs). The walls of a ground floor do not have both the horizontal and the vertical damp insulation. In the beginning period of their service life there was no damp insulation in building walls only the drainage system around a building and the town system of storm water drainage. Nowadays the walls of cellars and the walls of ground floors get damp because of the drainage system damages. The tenement-houses have rafter framing. The stairs generally have steel construction with the wooden stair treads, the richly decorated staircase railings can be found on the lower stories of the buildings.

Corresponding author: Mariusz Rejment

E-mail: mariusz.rejment@pwr.wroc.pl 
The paper presents the problem, which was selected from among a group of many problems concerning the revitalization of the down-town tenement-houses. The above problem was noticed and originally formulated by the authors of the paper.

The revitalization of the old down-town streets is a subject of the complex problems in domain of architecture, building engineering, economy as well as history of art and law (e.g. Kalibatas et al. 2011; Gronostajska 2008; Siozinyte et al. 2014; Siozinyte, Antucheviciene 2013; Medineckiene, Bjork 2011; Tupenaite et al. 2010; Staniunas et al. 2013). Therefore, with this complexity, the authors have chosen for further recognition the problems concerning the technical condition of the examined tenement-houses, adequacy of the technical condition to the prices of the tenement-houses on the real estate market and the economic effectiveness estimation of the revitalisation. Due to the lack of undeveloped building lots in the down-town streets it seems interesting to do the analyses, which might support the decision processes concerning the purchase of the tenement-houses in the down-town with taking into account in these decision processes the further destiny of the tenement-houses, i.e. to revitalize or to demolish and next to build a new building on a building lot.

In the research procedure the authors applied the principles of the value analysis (Miles 1972), the estimation methods of the physical deterioration degree of the tenement-houses (Ross 1928) and the economic formulas concerning the effectiveness of revitalisation projects (Kruijt 1974; Lunkevičius et al. 2001). The authors also applied in the paper remarks from the paper (Marcinkowska, Mrozowicz 1999). The research methodology elaborated by the authors assumed that the formulation of the particular stages of research in the praxeological sequence, which was done with taken into account the subject and the researches results obtained in succession.

The solution of a problem was elaborated on the base of:

- Technical analysis. The technical analysis (Chapter 2) comprises the estimations of physical deterioration degree of the tenement-houses. The calculated values are the base for the further researches.

- Analysis of technical-economic relations. The technical-economic analyses (Chapter 3) include the research of symmetrical relations among the technical elements and the economic elements. It comprises the research of mutual conformability between the physical deterioration degree of the tenement houses and their market prices with taking into account the price of a building lot.

- Economic analysis. The economic analyses (Chapter 4) concerns the economic reasons of a tenement house purchase with taking into account the variants of its further destination. In order to do the estimation the authors revised the existing economic formulas and selected and transformed the formulas proper for the aim of the problem solution. The solution was obtained by inserting the values gained in the previous stages of the analyses.

The researches results, according to such arrangement, are presented in the next part of the paper.

\section{Technical analysis}

The aim of the analysis is to estimate the physical deterioration degree of the tenement-houses in Wrocław. The physical deterioration degree is information about the technical usefulness of these tenement-houses to the revitalisation work. It also enables to do the analyses of the selling prices of the tenement-houses and to do the analyses, which enable to make decision about "to build or to repair?".

There are different procedure methods to estimate the physical deterioration degree of the tenement-houses $\left(\boldsymbol{S}_{\boldsymbol{Z}}\right)$. The first one consists in the estimation of the physical deterioration degree from the separate researches of the tenement-houses. The researches of the down-town tenement-houses in Wrocław comprise the group of 102 tenement-houses, and were done in the Department of Design Methods and Building Erection, the Institute of Building Engineering, Wrocław University of Technology (e.g. Marcinkowska, Mrozowicz 1999; Mrozowicz et al. 1996; Marcinkowska, Gawron 2006). The researches consist in doing the separate estimations of the physical deterioration degree of some particular tenement-houses elements, and next to estimate the weighted average physical deterioration degree of the whole tenement-house. The second method consists in applying the time methods (e.g. Kruijt 2008), with reference to the tenement-houses elements or to the whole tenementhouse. The physical deterioration degree (of an element or of a whole tenement-house) in the time methods is a function of durability and service life period. The form of function is connected to the level of maintenance accuracy of a building. The functions connected to the very careful method of tenement-house maintenance and the functions reflecting the bad maintenance of a tenementhouse were chosen for the description of the physical deterioration degree considering the historical service life of the tenement-houses in Wrocław. It has been noticed that it could be distinguished two extreme methods of maintenance in the whole service life period of the tenementhouses in Wrocław. The tenement-houses maintenance was very carefully from the moment of their erection till the year 1944. During those years the tenement-houses were a private property and the owners complied with the terms and range of the necessary maintenance and repairs. The owners also monitored how the tenants used the apartments. In 1945 the city of Wrocław was under military operations. After the II World War the tenementhouses were the public property. The local authorities or the country government or the local community administrated them. It was not paid a proper attention to the technical rules of the tenement-houses maintenance due 
to the post-war difficulties and in the later years the social and economic disorder. Therefore, it can be stated that the tenement-houses maintenance has been bad since the year 1945. As a result of that, the physical deterioration degree $\left(S_{Z}\right)$ of the tenement-houses from the moment of their erection till the year 1944 proceeded according to the Eytelwein and Ross's formulas (Ross 1928), i.e.:

$$
S_{Z}=\frac{t^{2}}{T^{2}} \cdot 100 \%
$$

where: $T$ - element or building durability, $t$ - period of service life of an element or a building.

In case of the examined tenement-houses:

$$
S_{Z 1}=\frac{t_{1}^{2}}{T^{2}} \cdot 100 \%,
$$

where: $S_{Z 1}$ - physical deterioration degree of a tenementhouse element or a tenement-house from the moment of its erection till the year $1944[\%] ; t_{1}$ - period of service life from the moment of its erection till the year 1944; $T$ - see Eqn (1).

The lineal function should be applied in the period from the year 1945 till the present after that year estimation of the physical deterioration degree $\left(S_{Z}\right)$. According to the lineal function the physical deterioration of a building is directly proportional to its age, i.e.:

$$
S_{Z}=\frac{t}{T} \cdot 100 \%,
$$

where: $T, t$ see Eqn (1).

In case of the examined tenement-houses:

$$
S_{Z 2}=\frac{\left(t_{2}-t_{1}\right)}{T} \cdot 100 \%,
$$

where: $T, t_{1}$ - see Eqn (2), $S_{Z 2}$ - physical deterioration degree of a tenement-house element or a tenement-house from the year 1944 till the moment of its present estimation; $t_{2}$ - period of service life from the moment of a tenement-house erection till the moment of its present estimation of the physical deterioration degree.

Equations (1) and (3) are applied to the equal method of a building maintenance in the period of its service life. Because of the fact that there are two historical periods of service life of the tenement-houses in Wrockaw the authors adapted Eqns (2) and (4). It was determined a course of the strait line $\left(t_{2}-t_{1}\right) / T$ form the point, which on parabola $t^{2} / T^{2}$ was marked by the point with coordinates $\left(S_{Z 1}, t_{1}\right)$ to the point with coordinates $\left(S_{Z}=100 \%\right.$, $t=T$ ). The above transformation enabled to describe the physical deterioration degree of the tenement-houses $\left(S_{Z}\right)$ by the formula, which takes into consideration the method of tenement-house maintenance to the year 1944 and the method of tenement-house maintenance from the year 1945 till the moment of its present estimation. The elaborated formula has the following form:

$$
S_{Z}=\left[\left(t_{2}-t_{1}\right) \cdot \frac{\left(1-S_{Z 1}\right)}{\left(T-t_{1}\right)}+S_{Z 1}\right] \cdot 100 \%,
$$

where: $S_{Z}$ - physical deterioration degree of the tenementhouses in period $t_{1}<t_{2} \leq T ; S_{Z 1}, T, t_{1}, t_{2}$ see Eqns (2), (4).

Some particular elements of a building or a building examined as one unit might be the subject of the estimation of the physical deterioration degree. In case, when some particular elements of a building are examined the physical deterioration degree of a whole building is calculated according to the equation:

$$
S_{Z}=\sum_{i=1}^{n} \frac{u_{e i} \cdot S_{e i}}{100 \%},
$$

where: $S_{Z}$ - physical deterioration degree of a whole building [\%]; $S_{e i}$ - physical deterioration degree of an element $i$ in a building, in [\%]; $u_{e i}$ - contribution of an element $i$ in the total cost of a building, in [\%]; $n-$ number of elements $i, i=1, \ldots, n$.

In order to select, from the presented above methods, the method which is proper for the aim of the examined problem it was done the comparison of the estimations of the physical deterioration degree of 85-years-old tenement-houses with the durability $T=120$ years, erected in the year 1914 according to the three variants of calculations, i.e.:

1. Equation (5) applied for some particular tenementhouse elements, and next the calculation of the physical deterioration degree of a whole tenement-house by Eqn (6).

2. Equation (5) applied for a whole tenement-house.

3. Application of the statistical researches (done in the year 1999) concerning the physical deterioration degree of the tenement-houses elements erected in the year 1914, i.e. for the tenement-houses with service life $t=85$ years (Marcinkowska, Mrozowicz 1999), and next the calculation of the physical deterioration degree for a whole tenement-house according to Eqn (6). The researches (Marcinkowska, Mrozowicz 1999) concerned the two variants of the technical estimation of elements, i.e.: a) the estimation of the present technical condition of an element; $b$ the estimation of element usefulness in case when a tenement-house is intended to a major repair, the above variant is a transformation of a situation connected to the tenement-houses revitalization.

The results of calculations, suitable for the above mentioned assumptions, are presented in Table 1.

The comparison calculations of the physical deterioration degree of the tenement-houses with the period of service life 85 years presented in Table 1 show the convergence of the results obtained according to variant 1 , variant 2 and variant $3 \mathrm{~b}$. The estimation resulting from variant of procedure $3 a$ and $3 b$ is closer (better transformed) to the specificity of the tenement-houses in Wrocław than the estimations done according to the general applied time methods. However the values obtained 
Table 1. Physical deterioration degree of some building elements and whole 85-year-old down-town tenement-houses in Wrocław

\begin{tabular}{|c|c|c|c|c|c|c|c|c|c|c|}
\hline \multirow{3}{*}{ No } & \multirow{3}{*}{ Building element } & \multirow{3}{*}{$\begin{array}{c}\text { Element } \\
\text { contribution in } \\
\text { cost of building } \\
\boldsymbol{u}_{\boldsymbol{i}}[\%]\end{array}$} & \multicolumn{4}{|c|}{$\begin{array}{c}\text { Physical deterioration degree } \boldsymbol{S}_{\boldsymbol{e} i} \text { according } \\
\text { to researches, [\%] }\end{array}$} & \multicolumn{4}{|c|}{$S_{e i}$ according to Eqn (5), [\%] } \\
\hline & & & \multicolumn{2}{|c|}{ Observed } & \multicolumn{2}{|c|}{$\begin{array}{l}\text { Considering major } \\
\text { repair }\end{array}$} & \multirow[t]{2}{*}{$T$} & \multirow[t]{2}{*}{$t_{2}^{*}$} & \multirow[t]{2}{*}{ Element } & \multirow{2}{*}{$\begin{array}{c}\text { Building } \\
(3 \times 10)\end{array}$} \\
\hline & & & Element & $\begin{array}{c}\text { Building } \\
(3 \times 4)\end{array}$ & $\begin{array}{c}\text { Element } \\
\boldsymbol{u}\end{array}$ & $\begin{array}{l}\text { Building } \\
(3 \times 6)\end{array}$ & & & & \\
\hline 1 & Earth work & 1.7 & 28.5 & 0.48 & 28.5 & 0.48 & (n.a.) & (n.a.) & 28.5 & 0.48 \\
\hline 2 & Foundations & 0.9 & 38.2 & 0.34 & 38.2 & 0.34 & 180 & 85 & 38.4 & 0.34 \\
\hline 3 & Insulations & 0.2 & 96.6 & 0.19 & 100.0 & 0.19 & (n.a.) & (n.a.) & 96.6 & 0.19 \\
\hline 4 & Main walls & 22.1 & 39.4 & 8.27 & 39.4 & 8.27 & 150 & 85 & 48.0 & 10.60 \\
\hline 5 & Partition walls & 3.7 & 37.2 & 1.38 & 95.0 & 3.50 & 100 & 85 & 80.5 & 2.98 \\
\hline 6 & $\begin{array}{l}\text { Floors and } \\
\text { balconies }\end{array}$ & 10.1 & 44.4 & 4.48 & 80.0 & 8.08 & $150 / 80$ & 85 & $48 / 99.0$ & 8.96 \\
\hline 7 & Stairs & 1.9 & 43.2 & 0.82 & 43.2 & 0.82 & 150 & 85 & 48.0 & 1.00 \\
\hline 8 & Rafter framing & 1.8 & 48.4 & 0.87 & 48.4 & 0.87 & 75 & 85 & 100.0 & 1.80 \\
\hline 9 & Roofing & 1.2 & 55.0 & 0.66 & 100.0 & 1.20 & 40 & 15 & 37.0 & 0.45 \\
\hline 10 & $\begin{array}{l}\text { Plasters and } \\
\text { sheet metal work }\end{array}$ & 7.3 & 44.8 & 3.27 & 50.0 & 3.65 & 60 & 85 & 100.0 & 7.30 \\
\hline 11 & Windows joinery & 6.5 & 51.3 & 3.33 & 100.0 & 6.50 & 50 & 85 & 100.0 & 6.50 \\
\hline 12 & Doors joinery & 4.7 & 40.3 & 1.89 & 80.0 & 3.76 & 80 & 85 & 100.0 & 4.70 \\
\hline 13 & Floors finishing & 6.6 & 55.8 & 3.68 & 100.0 & 6.60 & 100 & 85 & 80.5 & 5.30 \\
\hline 14 & Painting & 2.5 & 57.8 & 1.44 & 100.0 & 2.50 & (n.a.) & (n.a.) & 57.8 & 1.44 \\
\hline 15 & Furnaces & 6.3 & 48.4 & 3.05 & 100.0 & 6.30 & 40 & 30 & 50.0 & 4.72 \\
\hline 16 & $\begin{array}{l}\text { Sewerage and } \\
\text { water supply } \\
\text { system }\end{array}$ & 8.8 & 49.4 & 4.35 & 70.0 & 6.10 & (n.a.) & (n.a.) & 70.0 & 6.10 \\
\hline 17 & Gas system & 1.8 & 42.2 & 0.76 & 70.0 & 1.26 & (n.a.) & (n.a.) & 70.0 & 1.26 \\
\hline 18 & Wiring system & 2.1 & 46.9 & 0.99 & 70.0 & 1.46 & (n.a.) & (n.a.) & 70.0 & 1.46 \\
\hline 19 & $\begin{array}{l}\text { Locksmith and } \\
\text { blacksmith } \\
\text { elements }\end{array}$ & 0.4 & 41.0 & 0.16 & 41.0 & 0.16 & (n.a.) & (n.a.) & 41.0 & 0.16 \\
\hline \multirow[t]{2}{*}{20} & Others & 9.4 & 40.0 & 3.76 & 40.0 & 3.76 & (n.a.) & (n.a.) & 40.0 & 3.76 \\
\hline & \multicolumn{3}{|c|}{$\begin{array}{l}\text { Physical deterioration degree of a building } \\
\left(\boldsymbol{S}_{Z}\right) \text { according to Eqn (6) } \\
\text { Physical deterioration degree of a building } \\
\left(\boldsymbol{S}_{Z}\right) \text { calculated for a whole building, according } \\
\text { to Eqn }(5), \boldsymbol{S}_{Z}=\mathbf{6 3 . 8 0} \% \\
* \text { Period of service life } \boldsymbol{t}_{\mathbf{2}} \text { or period of service } \\
\text { life of an element, which was replaced. }\end{array}$} & 44.17 & & 65.72 & & & & 68.62 \\
\hline
\end{tabular}

according to variant 2 approach the obtained results to the values calculated according to variant $3 \mathrm{a}$. It could be of importance for the postponing the term of the revitalization work. The above analysis of the results accounts for acceptance to the further consideration the values obtained according to variant 2, i.e. Eqn (5) applied for a whole tenement-house. Because of the fact that in the next part of the paper the physical deterioration degree of the tenement-houses in Wrocław in the years 1991-2009 will be very interesting, Table 2 presents the specification of the numerical values concerning the physical deterioration of the tenement-houses in Wrocław erected in the year 1914 .
Table 2. Physical deterioration degree calculated according to formula (5) for a whole tenement-house

\begin{tabular}{l|l|l|l|l|l|l|l}
\hline \multicolumn{7}{c}{ Physical deterioration degree $\left(\boldsymbol{S}_{Z}\right)$} \\
\multicolumn{1}{c}{ of tenement-houses erected in $1914[\%]$} \\
\hline Year & 1991 & 1995 & 1997 & 1998 & 1999 & 2000 & 2003 \\
$S_{Z}[\%]$ & 55.4 & 59.5 & 61.6 & 62.7 & 63.8 & 64.7 & 67.9 \\
\hline Year & 2004 & 2005 & 2006 & 2007 & 2008 & 2009 & \\
$S_{Z}[\%]$ & 68.9 & 69.9 & 71.0 & 72.1 & 73.1 & 74.1 & \\
\hline
\end{tabular}


Conclusions from the technical analysis:

- The physical deterioration degree resulting from the direct monitoring of the tenement-house elements (Table 1, col. 4th) informs about the possibility of current use of the apartments in the down-town tenement-houses in Wrocław. However, it should be noticed that the wooden floors in these tenement-houses already exceeded the standard level of durability (Table 1, item 6, col. 8th) therefore the further use of the tenement-houses will be possible providing the major repairs, and it is also necessary to do the regular monitoring of the technical condition of the floors till the moment of the major repairs.

- The average values of the physical deterioration degree of the down-town tenement-houses in Wrocław (Table 2) present in the year 2009 show the necessity to make immediate decisions about their repair and modernisation or demolition and building a new tenement-house.

- The value of the physical deterioration degree of the tenement-houses calculated according to the Eqn (5) for the year 2009 is $S_{Z}=74.1 \%$ (Table 2). This value of the physical deterioration degree of a tenement-house (which surpasses 70\%) with taking into account the technical and economic conditions according to custom do not allow to start the repair or the modernisation work. However, it should be noticed that the technical conditions of the main walls and the foundations decides about sensibility of the major repair. It is because of the fact that the replacement of the floors causes that many other elements must be demolished or destroyed. Therefore, it is reasonable to check the physical deterioration degree individually for these elements calculated according to the Eqn (5). The above values, calculated for the year 2009, are the following: for the walls $S_{e}=56.0 \%$ and for the foundations $S_{e}=41.6 \%$ so they allow for the sensibility of the repair work.

- It should be also discussed the problem of the estimation of the service life period of the tenementhouses after the repair and modernisation work. According to the assumption that the technical condition of the main walls will not improve as a result of the major repair of the tenement-houses and the external conditions (e.g. connected with the communication infrastructure) do not accelerate the physical deterioration of the foundations, the period of service life of the tenement-houses after the major repair and modernisation can be estimated for minimum 25 years. Because in that moment the physical deterioration degree of the main walls, calculated according to Eqn (5), is $S_{e}=74 \%$ and the physical deterioration degree of the foundations is $S_{e}=61 \%$.

- The above conclusions, resulting from the technical analysis, do not indicate clear decisions about the problem of sensibility of the revitalisation of the tenement-houses in Wrocław. The solution of the problem requires the further analyses, among other things, which take into account the formation of the real estate's prices in the city centre (in the range of: tenement-houses prices, prices of new buildings and prices of building lots).

\section{Technical and economic analysis}

The technical and economic analysis consists in the research of market relations of the tenement-houses prices in relation to the new apartment buildings and in relation to their replacement cost. The research comprised the years 1991-2009, so it enables to examine the trends that form in this scope.

The offered prices of the tenement-houses were taken from (Real Estate Yearbooks 1991-2009). The data concerning the new build apartment houses and the building lots were obtained in the same way. The offered prices are used for the mutual comparison, what reduces the mistake/fault in relation to the difference with the transactions prices, which are usually negotiated individually.

The tendency course of purchase interest of the tenement-houses is presented in Table 3.

The prices in Table 3 (calculated for $1 \mathrm{~m}^{2}$ of usable area of apartment) were calculated as the average in the examined year from the sales tenders of 90-100 apartments and from a few to several sales tenders of small building lots in the down-town area of Wrocław. However, it should be noticed, that the collected offered prices do not disclose the method of the real estate estimation. There are a few method of real estate estimation (e.g. Hannonen 2008) and the selection of the method depends from the aim of the estimation. However, the base of the offer prices estimation was not significant for the aim of this paper.

The numerical values presented in Table 3 show the distinctly marked increase of interest of the tenementhouses in the period of 1991-2009. If in the year 1991 the price of the new apartment buildings was three times higher from the price of the tenement-houses, so in the year 2009 the above coefficient was only 1.49 (Table 3, col. 4th). If it is taken into account the increasing prices of building lots in these relations (Table 3, col. 5th) and assumed them in the price on the tenement-houses (Table 3 , col. 6th) so the relations between the price of the new apartment buildings and the price of the tenementhouses form, in these period, in the limits 3.24-2.05. It should be also noticed that in the period of years 19912009 the price of the new apartment buildings increased 13.6 times, the price of the tenement-houses increased 27.5 times and the price of the building lots 100 times. However the dynamics of increase marks particularly during the last years of this period. The presented data could be analysed as a phenomena of many social and economic transformations. However, in this paper it is interesting the connection of the indicated relations with the investors' tendency to the tenement-houses revitalization. From this reason it is very important to compare the real 
Table 3. The attractiveness tendency of the down-town tenement-houses in Wrocław (prices in $€ / 1 \mathrm{~m}^{2}$ of useable area)

\begin{tabular}{|c|c|c|c|c|c|c|c|}
\hline \multirow{3}{*}{ Year } & \multicolumn{3}{|c|}{ Tender price } & \multicolumn{4}{|c|}{ Building lot price } \\
\hline & \multirow{2}{*}{$\begin{array}{l}\text { new } \\
\text { buildings } \\
\quad[€]\end{array}$} & \multirow{2}{*}{$\begin{array}{l}\text { tenement- } \\
\text { houses } \\
{[€]}\end{array}$} & \multirow{2}{*}{$\begin{array}{c}\text { coefficient new buildings/ } \\
\text { tenement-houses } \\
{[\%]}\end{array}$} & \multirow{2}{*}{$\begin{array}{c}1 \mathrm{~m}^{2} \text { of a } \\
\text { building lot } \\
{[€]}\end{array}$} & \multirow{2}{*}{$\begin{array}{c}1 \mathrm{~m}^{2} \text { of } \\
\text { useable area } \\
{[€]}\end{array}$} & \multicolumn{2}{|c|}{ contribution in price } \\
\hline & & & & & & $\begin{array}{c}\text { new buildings } \\
{[\%]}\end{array}$ & $\begin{array}{c}\text { tenement-houses } \\
{[\%]}\end{array}$ \\
\hline 1991 & 143 & 48 & 300 & 14 & 4 & 2.5 & 7.5 \\
\hline 1995 & 333 & 107 & 311 & 38 & 10 & 3.0 & 8.8 \\
\hline 1997 & 476 & 238 & 200 & (n.a.) & (n.a.) & (n.a.) & (n.a.) \\
\hline 1998 & 548 & 286 & 191 & (n.a.) & (n.a.) & (n.a.) & (n.a.) \\
\hline 1999 & 571 & 333 & 171 & (n.a.) & (n.a.) & (n.a.) & (n.a.) \\
\hline 2000 & 583 & 381 & 153 & 119 & 30 & 5.0 & 7.8 \\
\hline 2003 & 667 & 428 & 155 & 143 & 36 & 5.4 & 8.3 \\
\hline 2004 & 714 & 476 & 150 & (n.a.) & (n.a.) & (n.a.) & (n.a.) \\
\hline 2005 & 833 & 524 & 159 & 238 & 60 & 7.1 & 11.4 \\
\hline 2006 & 1071 & 667 & 156 & 381 & 95 & 8.8 & 14.3 \\
\hline 2007 & 1905 & 1262 & 151 & 857 & 214 & 8.8 & 17.0 \\
\hline 2008 & 1952 & 1310 & 149 & 1190 & 298 & 16.6 & 22.7 \\
\hline 2009 & 1952 & 1310 & 149 & 1428 & 357 & 18.3 & 27.3 \\
\hline
\end{tabular}

technical degree of the tenement-houses with the physical deterioration degree for which the price corresponds with. For this purpose it was elaborated the relation, which is determined as the supplementary physical deterioration degree $\boldsymbol{S}_{Z z}$. It is described by the formula:

$$
S_{Z_{Z}}=\left(1-\frac{W_{b}}{W_{o}}\right) \cdot 100 \%,
$$

where: $W_{b}$ - present value of a building (price of a tenement-house); $W_{o}$ - reconstruction value (price of a new apartment building) and the analogical relation determined as the supplementary physical deterioration degree $S_{Z Z G}$, which takes into account the price of a building lot in the price of a tenement-house.

Table 4 presents the comparison of the real physical deterioration degree of the tenement-houses and the supplementary physical deterioration degree of the tenementhouses calculated according to Eqn (7).

Conclusions from the technical and economic analysis:

- In the years 1991-2009 it is observed the considerable increased tendency of the purchase demand of the tenement-houses in the down-town districts of Wrocław.

- The dynamics of increase of the building lots prices (Table 3, col. 5th) showed distinctly after the year 2005 has not yet found the adequate transformation on the prices of the tenement-houses and the prices of the new apartment buildings.

- Since the year 1997 it has been observed the overestimation of the prices of the tenement-houses in comparison with their replacement cost (Table 4, col. 3rd) and to their replacement cost examined together with the value of building lot (Table 4, col. 4th).
Table 4 . The comparison of the real $S_{Z}$ and the supplementary $S_{Z Z} S_{Z Z G}$ physical deterioration degree of the down-town tenement-houses in Wrocław

\begin{tabular}{c|c|c|c}
\hline \multirow{2}{*}{ Year } & \multicolumn{2}{|c|}{$\begin{array}{c}\text { Without price } \\
\text { of a building lot }\end{array}$} & $\begin{array}{c}\text { With price of a } \\
\text { building lot }\end{array}$ \\
\cline { 2 - 4 } & $\begin{array}{c}\text { physical } \\
\text { deterioration } \\
\boldsymbol{S}_{\boldsymbol{Z}} \\
\text { calculated } \\
\text { according to } \\
\text { Table 2 }\end{array}$ & $\begin{array}{c}\text { physical } \\
\text { deterioration } \\
\boldsymbol{S}_{\boldsymbol{Z}} \\
\text { calculated } \\
\text { according to } \\
\text { Eqn (7) }\end{array}$ & $\begin{array}{c}\text { physical } \\
\text { deterioration } \\
\boldsymbol{S}_{\boldsymbol{Z Z G}} \\
\text { calculated } \\
\text { according } \\
\text { to Eqn (7) }\end{array}$ \\
\hline 1991 & {$[\%]$} & {$[\%]$} & {$[\%]$} \\
1995 & 55.4 & 67.0 & 69.0 \\
1997 & 59.5 & 68.0 & 77.0 \\
1998 & 61.6 & 50.0 & (n.a.) \\
1999 & 62.7 & 48.0 & (n.a.) \\
2000 & 64.7 & 42.0 & (n.a.) \\
2003 & 67.9 & 35.0 & 36.0 \\
2004 & 68.9 & 36.0 & 41.0 \\
2005 & 69.9 & 33.0 & (n.a.) \\
2006 & 71.0 & 32.0 & 44.0 \\
2007 & 72.1 & 37.0 & 46.0 \\
2008 & 73.1 & 32.0 & 45.0 \\
2009 & 74.1 & 33.0 & 48.0 \\
\hline & & 33.0 & 51.0 \\
\hline
\end{tabular}

- The supplementary physical deterioration degree of the tenement-houses $S_{Z Z}$ and $S_{Z Z G}$ (Table 4, col. 4th, col. 5th) is not adequate to the physical deterioration degree calculated with taking into account the major repair needs (Table 1, col. 6th). The physical deterioration of the tenement-houses balanced by the price (Table 4, col. 3rd, col. 4th) has values nearing 
to the observed physical deterioration degree (Table 1, col. 5th).

- The above analysis enables to draw some conclusions about the lack of decided tendencies of investors about the tenement-houses revitalization. The technical condition of the tenement-houses still enables to use the tenement-houses on the level of low service standard, but it also determines the moment, in which the lack of major repair can cause to the demolition of the tenement-houses and the profitable use of a building lot. In this decision situation it is necessary for making decision the economic analysis showing the effectiveness of the revitalization or erecting a new building.

\section{Economic analysis}

Due to the lack of settled indications concerning the further procedure with the tenement-houses erected in the beginning of the XX century it should have been used from the experience of the European countries, which noticed the above problem much earlier. Since the mid of sixties the above problem has been a subject of many discussions started by economists (e.g. Kruijt 1974, 2008; Lin et al. 1990; Needleman 1965, 1968, 1969; Mayo 1981; Goodman 2002; Sigsworth, Wilkinson 1967). The European economists proposed the economic criteria, in which some authors applied the discount calculation and other authors applied the simple calculation and also the simple calculation with taking into account the market methods. The proposed formulas also have different expansion in the scope of the factors describing the project effectiveness.

The aim of the economic analysis is the selection of a formula proper for the situation of the tenementhouses in Wrocław. It should be taken into account the significant physical deterioration degree of the tenementhouses and inadequacy of the tenement-houses price to their technical condition. It is assumed that the interested investor is the only purchaser of a tenement-house. It is because of the fact that these buildings are usually in the local government-private community, which usually do not have capital to do the revitalization work.

The two possible variants of decisions process made by investors were examined, i.e.:

- Variant I. Repair and modernization.

- Variant II. Demolition and building a new tenementhouse.

Additionally it was done the analysis of a situation of a purchase including the estimation of the limit price, which (from a purchaser point of view) is sensible considering the chosen variant of procedure.

The following economic criteria were the subject of the analysis:

- The Needleman's formulas (Needleman 1965) - the modernization is profitable if the following dependence takes place:

$$
C>R+M \frac{1-(1+i)^{-n}}{i}+\frac{C}{(1+i)^{n}},
$$

where: $C$ - cost of demolition and building a new tenement-house; $R$ - cost of modernization; $i$ - discount index; $n$ - service life period after the modernization; $M$ difference in the yearly costs of repair of a new building and a modernized building.

The formula modified with the increase of the reconstruction costs in period " $n$ ":

$$
C>R+M \frac{1-(1+i)^{-n}}{i}+\frac{C(1+z)^{n}}{(1+i)^{n}},
$$

where: $z$ - yearly index of increase of the reproduction price; $R, i, n, M-$ see Eqn (8).

- The Schaf's formula (Sigsworth, Wilkinson 1967) the modernization is profitable if the following dependence takes place:

$$
C>R+M \frac{1-(1+i)^{-n}}{i}+C \frac{(1-n \cdot r)}{(1+i)^{n}}++D \frac{1-(1-\mathrm{i})^{-n}}{i}
$$

where: $D$ - difference of rent in a new building and in a modernized building; $r$-yearly percent of a new building depreciation; $R, i, n, M-$ see Eqn (8).

The analysis of the presented Eqns enables to notice that the Needleman's formulas (8) and (9) do not take into account the difference in standards of a new tenement-house and a modernized tenement-house. In case of the tenement-houses in Wroclaw (which have a considerable physical deterioration degree and disused useful function) it is planned a wide scope of the modernization work.

The factors describing the Needleman's formulas (8) and (9) and the Schaf's formula (10) are mainly connected with the construction industry. A building specialist should estimate the cost of demolition and the cost of building a new tenement-house $(C)$, the modernization cost $(R)$, and difference in the yearly costs of repairs of a new tenement-house and a modernized tenement-house, the period of service life after the modernization $(n)$ and the yearly percent of a tenement-house depreciation $(r)$. The above values are determined, possible to estimate with a little tolerance of a mistake. However, about the calculated result of the formulas decides the values from the field of economy, among other things the value of discount rate $(i)$, which in the period of service life $(n)$ will be formed according to the random variable, the values $(D)$ and $(z)$ will be formed in the similar way. Therefore, the calculations according to the Eqns (8), (9), (10) have a probabilistic character. At the same time as a result of the physical deterioration degree of the tenement-houses the decisions about their revitalization should be taken and done in the coming years. The above fact implies the short-term of investor's activities.

The critical analysis of the usefulness of the above Eqns, i.e. (8), (9), (10) was done in the paper of Rosenfeld 
and Shohet (1999). Moreover, the authors in that paper also noticed that the problem of renovating vs. rebuilding has received only limited attention in the professional literature. The buildings repairs and modernization is a manifold problem and the authors of the papers mostly focus to the problems concerning: building lifecycle management (Vanlande et al. 2008), repairs work organisation (Juan et al. 2009b), housing condition assessment and refurbishment strategies (Juan Kim et al. 2009a).

Taking into account the presented above argumentation it is well founded to apply the Kruijt's Eqn (11) and the Eqns (12) and (13) for the estimation concerning the economic effectiveness of the revitalization work.

The Kruijt's formula (Kruijt 1974, 2008) - modernization is profitable if the following dependence takes place:

$$
C_{t}-V_{n}>R_{t}-V_{m},
$$

where: $C_{t}-$ cost of building a new tenement-house together with the price of purchase of a real estate; $V_{n}$ - real estate market price of a new tenement-house; $R_{t}$ - modernization costs together with price of real estate; $V_{m}-$ real estate market price after modernization.

The upper limit of investments on the modernization:

$$
V_{m}=W_{m}+K_{m},
$$

where: $V_{m}$ - see Eqn (11); $W_{m}$ - the maximum price, which is worth to pay for real estate purchasing; $K_{m}-$ modernization cost.

The upper limit of investments on building a new tenement-house:

$$
V_{n}=W_{m}+K_{n},
$$

where: $K_{n}$ - cost of building a new tenement-house; $V_{n}$, $W_{m}-$ see Eqn (12).

In application of Eqn (11) it was estimated the economic effectiveness of the revitalization of the tenementhouses in Wrocław. The following data were assumed for the calculations:

$$
C_{t}=C_{n}+K_{w}+K_{w} \cdot\left(W_{r}+W_{z}+W_{o}+W_{p}\right),
$$

where: $C_{t}$ - see Eqn (11); $C_{n}$ - purchase price of a real estate, to $1 \mathrm{~m}^{2}$ of useable area, according to Table $3 ; K_{w}-$ cost of building $1 \mathrm{~m}^{2}$ of usable area in Wrocław in the year 2009, according to Announcement of Lower Silesian Voivode 23.09.2009 about the calculation indexes of repair cost of $1 \mathrm{~m}^{2}$ of useable area of apartment buildings (2009); $K_{n}=1156.00 € / 1 \mathrm{~m}^{2}$ (it is an average value, in separate, detailed cost estimation $K_{n}$ should be calculated according to a preliminary design); $W_{r}$ - increasing index due to demolition of existing tenement-house, $W_{r}=0.10$; $W_{z}$ - increasing index due to necessity of protection of existing neighbourhood tenement-houses construction, $W_{z}=0.04$ (the values of indexes $W_{r}$ and $W_{z}$ were assumed according to authors' knowledge and experience in cost calculation of construction work, in separate, detailed cost estimation, index $W_{r}$ should be calculated according to a preliminary design); $W_{o}$ - increasing index due to limited building site dimensions, $W_{o}=1.02$ (the value of index $W_{o}$ is agreed between an investor and a contractor of construction work, it depends on the conditions on a building site, its value is about several percent of a building erection cost); $W_{p}$ - increasing index due to design work, $W_{p}=0.10$ (the value of index $W_{p}$ were assumed according to design costs in the town of Wrocław (from $1.5 \%$ to $12 \%$ ) of building erection cost and particular investor's demands).

The aim of indexes $\left(W_{r}, W_{z}, W_{o}, W_{p}\right)$ application is to pay attention to the factors of the cost increase of construction work in case of rebuilding in comparison with a new building and to get to know in average course of the value of this cost increase:

$$
R_{t}=C_{n}+S_{Z} \cdot K_{w}+\left(S_{z} \cdot K_{w}\right) \cdot\left(W_{o}+W_{p}+W_{e}\right),
$$

where: $R_{t}$ - see Eqn (11); $S_{z}$ - according to Table 2; $C_{n}$, $K_{w}, W_{o}, W_{p}$ see Eqn (14); $W_{e}$ - increasing index repair work, $W_{e}=0.08$.

The calculation result shows, that the investments on the revitalization work $\left(R_{t}\right)$ consists in the limit $85 \%$ of investments on building of a new tenement-house $\left(C_{t}\right)$. However the prices of apartments in the tenement-houses after the revitalization work do not differ much from the prices of the new tenement-houses. The apartments in the tenement-houses after the revitalization work are sought because of the fact of the specific microclimate of a dwelling place, height of rooms, as well as prestige. From these reason it was assumed the equal $\left(V_{n}=V_{m}\right)$ real estate market value of apartments for both variants (according to Table 3, col. 2nd) for the price level from the year 2009. According to the above assumptions the inequality (11) does not satisfy, what shows that the tenement-houses revitalization is a profitable project.

In the both variants the authors did not take into account the increase of costs resulting from the particular conservatory conditions as well as the differences in the energetic characteristics of the tenement-houses after the revitalisation and the new tenement-houses (e.g. Marcinkowska, Rejment 1997, 2006). The authors also did not take into account the increase of costs resulting from the estimation and selection of contractor of conservatory and repair work, as it was noticed in Zavadskas et al. (2009).

In order to estimate the sensibility of the investor intentions at the moment of making a decision about a purchase of a real estate (a tenement-house) the Eqns (12) and (13) were modified. The modification consists in transformation of these formulas to the form showing the maximum purchase prices at which the activities described by variant I and variant II are economic effective.

For variant $I$ it is a calculation of the maximum price $\left(W_{m, I}\right)$ for which it is profitable to pay for a real estate, 
which is intended to be modernized and repaired according to the formula:

$$
\boldsymbol{W}_{m, I} \leq V_{n}-\left[S_{z} \cdot K_{w}+\left(S_{z} \cdot K_{w}\right) \cdot\left(W_{o}+W_{p}+W_{e}\right)\right]
$$

where: $W_{m}-$ see Eqn (12); $V_{m}-$ see Eqn (11); $S_{z}, K_{w}, W_{o}$, $W_{p}, W_{e}-$ see Eqn (15).

The calculations done according to Eqn (16) for the conditions in Wrocław, assuming the numerical data given in the description of Eqns (14) and (15) and the numerical data from Table 3, assuming $V_{m}=V_{n}$ (with justified as in the calculation according to Eqn (11), for the price level in the year 2009) show $W_{m, I} \leq 924.00 € / 1 \mathrm{~m}^{2}$ of useable area.

For variant II it is a calculation of the maximum price $\left(W_{m, I I}\right)$, which is profitable to pay for a real estate, which is intended to be demolished and to be built a new tenement-house according to the Eqn:

$$
W_{m I} \leq V_{n}-K_{w}+K_{w} \cdot\left(W_{r}+W_{z}+W_{o}+W_{p}\right),
$$

where: $W_{m}-$ see Eqn (12); $V_{n}-$ see Eqn (11); $K_{w}, W_{r}, W_{z}$, $W_{o}, W_{p}-$ see Eqn (14).

The calculations done according to Eqn (17) assuming the numerical data given in the description of Eqn (14) and the data from Table 3 (for the prices level in the year 2009) show $W_{m, I I} \leq 496.00 € / 1 \mathrm{~m}^{2}$ of useable area.

Conclusions from the economic analysis:

- The estimation of the economic effectiveness of the tenement-houses revitalization in Wrocław shows the usefulness of the repair work and the modernization work of the tenement-houses in the technical condition representing their average physical deterioration degree in the year 2009.

- The maximum profitable price of purchase of a real estate in case of its repair and modernization surpasses the maximum profitable price of purchase of a real estate in case of its demolish and building a new tenement-house about $86 \%$. Therefore it is essential to undertake a decision about the future destiny of a real estate before the purchase.

- In the both variants of procedure the maximum profitable price of purchase of a real estate surpasses the present price of land purchase (in the year 2009) (Table 3, col. 6th).

\section{Conclusions}

The tenement-houses in Wrocław erected in the beginning of the XX century are in the limited physical deterioration condition, in which they can be categorised for the repair and modernization work. However the analyses show that it is still a technical condition, in which the revitalization work of the tenement-houses is more profitable than their demolition and building a new tenement-house.

The construction scheme of the tenement-houses (longitude, with three sections), the height of floor and many chimneys (built for furnace heating service) enable to adapt the tenement-house for other functions than apartments. The change of the tenement-houses function (e.g. for head offices of firms, hotels, catering business) is attractive from the point of view of their down-town localization. The revitalization projects of the tenement-houses connected with the adaptation of their present function (i.e. apartments) to other destiny will be characterized by much better economic effectiveness than estimated in the paper.

In particular chapters of the paper the authors presented the numerical data concerning the technical features of the tenement-houses, the economic indexes and the results from the calculations. It should be noticed that the above numerical data has a character of the average values and as such they cannot be directly transformed to an individual real estate. However, the conclusions elaborated in the chapters with the technical scope, technicaleconomic and economic have an importance, which are generally obligatory for the tenement-houses in Wrocław erected in the beginning of the XX century.

\section{References}

Announcement of Lower Silesian Voivode 23.09.2009 about the calculation indexes of repair cost of $1 \mathrm{~m}^{2}$ of useable area of apartment buildings. Silesia, Poland.

Goodman, A. C. 2002. Estimating equilibrium housing demand for "stayers", Journal of Urban Economics 51(1): 1-24. http://dx.doi.org/10.1006/juec.2001.2234

Gronostajska, B. 2008. The affect of human feelings on creation of housing, Archives of Civil and Mechanical Engineering 8(1): 107-117. http://dx.doi.org/10.1016/S1644-9665(12)60270-2

Hannonen, M. 2008. Predicting urban land prices: a comparison of four approaches, International Journal of Strategic Property Management 12(4): 217-236. http://dx.doi.org/10.3846/1648-715X.2008.12.217-236

Juan, Y.-K.; Kim, J. H.; Roper, K.; Castro-Lacouture, D. 2009a. GA-based decision support system for housing condition assessment and refurbishment strategies, Automation in Construction 18(4): 394-401.

http://dx.doi.org/10.1016/j.autcon.2008.10.006

Juan, Y.-K.; Perng, Y.-H.; Castro-Lacouture, D.; Lu, K.-S. 2009b. Housing refurbishment contractors selection based on a hybrid fuzzy-QFD approach, Automation in Construction 18(2): 139-144.

http://dx.doi.org/10.1016/j.autcon.2008.06.001

Kalibatas, D.; Zavadskas, E. K.; Kalibatiene, D. 2011. The concept of the ideal indoor environment in multi-attribute assessment of dwelling-houses, Archives of Civil and Mechanical Engineering 11(1): 89-101. http://dx.doi.org/10.1016/S1644-9665(12)60176-9

Kruijt, B. 1974. De prijsontwikkeling op de tweedehands gebouweenmarket: Dissertatie Amsterdam UvA. Economisch Institunt voor de Bouwnijverheid. Deventer, Kluwer.

Kruijt, B. 2008. The changing spatial pattern of firms in Amsterdam: empirical evidence, Tijdschrift voor Economische en Sociale Geografie 70(3): 144-156. http://dx.doi.org/10.1111/j.1467-9663.1979.tb01435.x

Lin, C. C.; Soong, T. T.; Natke, H. G. 1990. Real time system identification of degrading structures, Journal of Engineering Mechanics 116(10): 2258-2274. http://dx.doi. org/10.1061/(ASCE)0733-9399(1990)116: 10(2258)

Lunkevičius, S.; Ustinovičius, L.; Zavadskas, E. K. 2001. Possibilities of revitalization of unused rural property, Journal 
of Civil Engineering and Management 7(1): 44-55. http://dx.doi.org/10.1080/13921525.2001.10531698

Marcinkowska, E.; Gawron, K. 2006. Down-town tenementhouses as an subject of real estate sales, in Technology and Management in Construction Industry, Scientific Works of Institute of Building Engineering, Wroclaw University of Technology, No 87, WUT Publishing House, 315-324.

Marcinkowska, E.; Mrozowicz, J. 1999. Physical deterioration degree of buildings and buildings elements as an element of real estate pricing, Rzeczoznawcza Małopolski No 5/6, 43-50.

Marcinkowska, E.; Rejment, M. 1997. Quantitative description of project solution producibility of apartment houses thermorenovations, Archives of Civil Engineering 43(2): 189-198.

Marcinkowska, E.; Rejment, M. 2006. Effect of risk on economic efficiency of overcladding system, Journal of Civil Engineering and Management 12(3): 247-253.

Mayo, S. K. 1981. Theory and estimation in the economics of housing demand, Journal of Urban Economics 10: 95116. http://dx.doi.org/10.1016/0094-1190(81)90025-5

Medineckiene, M.; Bjork, F. 2011. Owner preferences regarding renovation measures - the demonstration of using multicriteria decision making, Journal of Civil Engineering and Management 17(2): 284-295. http://dx.doi.org/10.3846/13923730.2011.582380

Miles, L. D. 1972. Techniques of value analysis and engineering. New York: Mcgraw-Hill. 320 p.

Mrozowicz, J.; Podolski, B.; Gawron, K. 1996. Repair of rental buildings in historical down-town development, in the VII Scientific and Technology Conference "Repairs Problems in Civil Engineering”, 1996, Wrocław: Szklarska Poręba, Poland, 333-339.

Needleman, L. 1965. The economics of housing. London: Staples Press. 232 p.

Needleman, L. 1968. Rebuilding of renovation? A reply, Urban Studies 5(1): 86-90. http://dx.doi.org/10.1080/00420986820080061

Needleman, L. 1969. The comparative economics of improvement and new building, Urban Studies 6(2): 196-209. http://dx.doi.org/10.1080/00420986920080261
Real Estate Yearbooks 1991-2009. Lower Silesian Guide Book, Poland.

Rosenfeld, Y.; Shohet, I. M. 1999. Decision support model for semi-automated selection of renovation alternatives, Automation in Construction 8: 503-505. http://dx.doi.org/10.1016/S0926-5805(98)00097-1

Ross, F. W. 1928. Leitfaden für die Ermittlung des Bauwertes von Gebäuden. Hannover: Verlag. 167 p.

Sigsworth, E. M.; Wilkinson, R. K. 1967. Rebuilding or renovation?, Urban Studies 4(2): 119-126.

http://dx.doi.org/10.1080/00420986720080231

Siozinyte, E.; Antucheviciene, J. 2013. Solving the problem of daylighting and tradition continuity in a reconstructed vernacular building, Journal of Civil Engineering and Management 19(6): 873-882.

http://dx.doi.org/10.3846/13923730.2013.851113

Siozinyte, E.; Antucheviciene, J.; Kutut, V. 2014. Upgrading the old vernacular building to contemporary norms: multiple criteria approach, Journal of Civil Engineering and Management 20(2): 291-298.

http://dx.doi.org/10.3846/13923730.2014.904814

Staniunas, M.; Medineckiene, M.; Zavadskas, E. K.; Kalibatas, D. 2013. To modernize or not: ecological-economical assessment of multi-dwelling houses modernization, Archives of Civil and Mechanical Engineering 13(1): 8898. http://dx.doi.org/10.1016/j.acme.2012.11.003

Tupenaite, L.; Zavadskas, E. K.; Kaklauskas, A.; Turskis, Z.; Seniut, M. 2010. Multiple criteria assessment of alternatives for built and human environment renovation, Journal of Civil Engineering and Management 16(2): 257-266. http://dx.doi.org/10.3846/jcem.2010.30

Vanlande, R.; Nicolle, C.; Cruz, C. 2008. IFC and building lifecycle management, Automation in Construction 18(1): 70-78. http://dx.doi.org/10.1016/j.autcon.2008.05.001

Zavadskas, E. K.; Kaklauskas, A.; Vilutiene, T. 2009. Multicriteria evaluation of apartment blocks maintenance contractors: Lithuanian case study, International Journal of Strategic Property Management 13(4): 319-338. http://dx.doi.org/10.3846/1648-715X.2009.13.319-338

Ewa MARCINKOWSKA. She is a retired Professor of Wrocław University of Technology but she still works as a lecturer at the Faculty of Civil Engineering of Wrocław University of Technology. She specializes in: application of the decision-making theory in the field of construction (including multi-criteria analysis and evaluation); technical and functional deterioration of constructions; technical and economic efficiency of modernization. She participated in the following research projects: Method of evaluation and preliminary optimization of housing designs, Evaluation system of negative functional properties of apartment buildings erected of large panel elements (development projects, Design and Research Centre of Civil Engineering, Warsaw, Poland), Evaluation system of technical and functional parameters of commercial constructions (National Development Project - PR-5), Technological and economic efficiency of thermal overcladding of residential buildings (grant, the Committee for Scientific Research), Diagnosis of damage causes and repair methods of housing estates in Lubin, Poland (research project, Mining and Metallurgical Combine Copper in Lubin).

Krzysztof GAWRON. He is an Assistant Professor of Civil Engineering at the Department of Construction Methods and Management at the Faculty of Civil Engineering of Wrocław University of Technology, Poland. He is also a Director of the Centre for Continuing Education of Wrocław University of Technology, a Leader of Development Strategy of Wrocław University of Technology and a Head of Postgraduate Studies "Real Estate Management. Management-Maintenance-Valuation". He specializes in technology and organization of construction work (including in particular the scheduling of construction work) as well as the real estate maintenance, management and property valuation. Now, he participates in a research project of the Ministry of Science and Higher Education "Knowledge Map Management System in a Construction Company".

Mariusz REJMENT. He is an Assistant Professor of Civil Engineering at the Department of Construction Methods and Management at the Faculty of Civil Engineering of Wrocław University of Technology, Poland. He received his M.Sc. and D.Sc. degrees in Civil Engineering at the Faculty of Civil Engineering of Wrocław University of Technology between 1993 and 2001 years, respectively. He is also actively involved in construction management as a site engineer/supervisor and as a quantity surveyor. He is a member of Lower Silesia Chamber of Civil Engineers. He has a Professional Civil Engineering Licence. He specializes in construction engineering with a focus on cost calculation of construction work, technology and organization of construction work, prefabrication in construction as well as real estate maintenance. 